\title{
Challenges Facing People Living With Hiv/Aids In Getting Social Support in Kano State, Nigeria: A Sociological Perspective
}

Auwalu Sale Yakasai, Norizan Abdul Ghani

To Link this Article: http://dx.doi.org/10.6007/IJARBSS/v11-i2/8663

DOI:10.6007/IJARBSS/v11-i2/8863

Received: 21 December 2020, Revised: 16 January 2021, Accepted: 15 January 2021

Published Online: 05 February 2021

In-Text Citation: (Yakasai \& Abdul Ghani, 2021)

To Cite this Article: Yakasai, A. S., \& Abdul Ghani, N. (2021). Challenges Facing People Living With Hiv/Aids In Getting Social Support in Kano State, Nigeria: A Sociological Perspective. International Journal of Academic Research in Business and Social Sciences, 11(2), 202-211.

Copyright: (c) 2021 The Author(s)

Published by Human Resource Management Academic Research Society (www.hrmars.com) This article is published under the Creative Commons Attribution (CC BY 4.0) license. Anyone may reproduce, distribute, translate and create derivative works of this article (for both commercial and non-commercial purposes), subject to full attribution to the original publication and authors. The full terms of this license may be seen at: http://creativecommons.org/licences/by/4.0/legalcode

Vol. 11, No. 2, 2021, Pg. 202 - 211

Full Terms \& Conditions of access and use can be found at http://hrmars.com/index.php/pages/detail/publication-ethics 


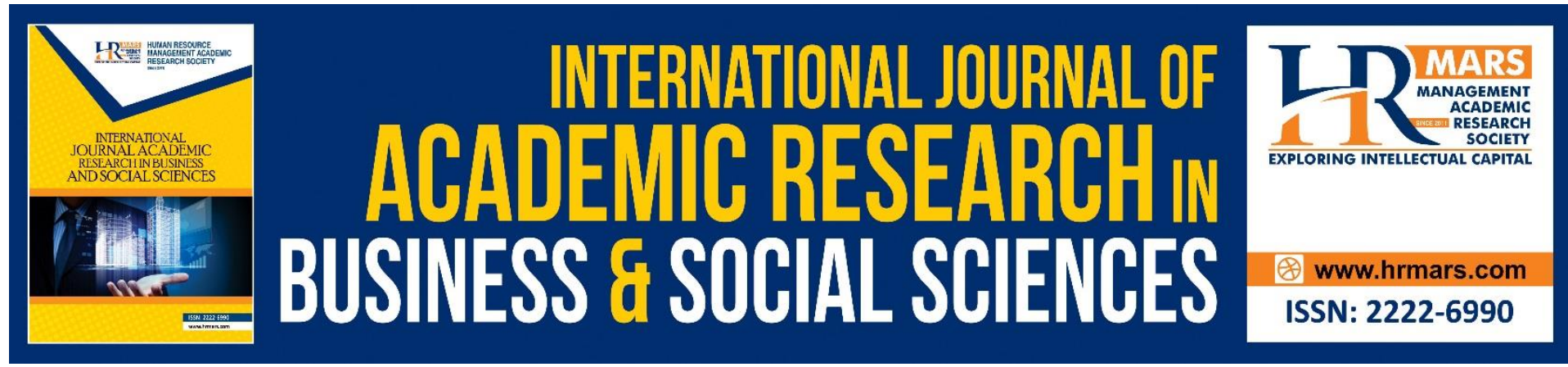

\title{
Challenges Facing People Living With Hiv/Aids In Getting Social Support in Kano State, Nigeria: A Sociological Perspective
}

\author{
Auwalu Sale Yakasai, Norizan Abdul Ghani \\ Faculty of Applied Social Sciences, Universiti Sultan Zainal Abidin, Terengganu, Malaysia \\ Email: si3249@putra.unisza.edu.my,norizabd@unisza.edu.my
}

\begin{abstract}
This paper aims to assess the challenges facing people living with HIV/AIDS in getting social support in Kano state, Nigeria and its effect on their daily life and health status. The study is qualitative and the data were therefore collected from 12 participants using the interview technique as an instrument for data collection and were finally analysed using Atlas. ti People living with Human Immunodeficiency Virus and Acquired Immunodeficiency Disease Syndrome usually face some challenges depending on the environment they live in. Some of the major challenges facing people living with HIV/AIDs worldwide include stigma and discrimination. Discrimination could be in terms of education, employment, marriage, friendship, social interaction and the rest. But the findings of the research clearly showed that there are laws and policies made by the government to protect the right of people living with HIV/AIDS in the state this reduced significantly the level of stigma and discrimination against PLWHA. The patients were employed in both public and private sectors, they had an equal educational opportunity and they had free access to social amenities as well as healthcare facilities in the state. They also got free antiretroviral therapy. Nevertheless, people living with HIV/AIDs were facing some challenges that are peculiar to their environment which involved: lack of involvement of religious leaders in the state HIV/AIDS affairs, lack of viral load test gadgets, withdrawal of international donors, At the end of this paper, recommendations will be made on how to truncate the challenges facing PLWHA in the state. Keywords: Challenges, Social Support, HIV/AIDS, Discrimination, Nigeria.
\end{abstract}

\section{Introduction}

A new disease known as Acquired Immune Deficiency Syndrome (AIDS) was first identified in 1881 after growing numbers of young homosexual men submitted to unusual opportunistic infections and occasional malignancies (CDC, 1981; Greene, 2007). A retrovirus, presently called human immunodeficiency virus type 1 (HIV-1), was subsequently recognized as the causative agent of what has since become one of the most devastating infectious diseases to have emerged in contemporary history (Barre-Sinoussi et al., 1983; Gallo et al., 1984; Popovic et al., 1984). The diagnosis of the first two cases of AIDS in Nigeria was made in 1985 and reported in 1986 in Lagos one of which was a young female sex worker of 13 years old from 
one of the West African nations (Nasidi \& Harry, 2006). Nigeria is the second nation with the highest incidence of HIV/AIDS in Africa after South Africa. The research was conducted to assess social support for people living with HIV/AIDS in Kano State, Nigeria. The state is located in the North West of Nigeria and it is one of the most populated states in the country and is a commercial centre. Nigeria has almost 3.8 million people living with HIV, the secondlargest universally (Odimegwu, Akinyemi \& Alabi, 2017). Relevant literature was review to serve as a guide to the study. The data were collected employing an interview from 12 participants and analysed using Atlas. ti 8 . The results showed that people living with HIV/AIDS in Kano State faced certain challenges such as lack of viral load test machines, disclosure of HIV status, frequent visits to collect treatment, etc. recommendations were made to overcome the identified challenges.

\section{Literature Review}

Moomba and Wyk, (2019) disclose that some patients were far from the health facilities and have difficulties in making follow-up clinic appointments, particularly during the rainfall period. In a study conducted between October 2006 and April 2007 with People Living with HIV and AIDS by the University of Botswana research team covering Gaborone, Gabane and Gaphatshwa areas of Botswana to discover challenges facing PLWHA and recognize suitable intervention strategies, challenges such as stigma and discrimination, denial and fear of disclosure, as well as risky sexual behaviors were discovered to be widespread. Underlying these challenges were stigmatizing behaviours, mainly associated with fear of HIV rather than with the means of the infection (Ntseane et al., 2010). Furthermore, concealing the HIV positive status as a key surviving strategy was popular in the family environment. This is as a result of searching for social support to keep family harmony because families are scared of getting the infection and losing their social respect in their communities (Shrestha et al., 2014). Moreover, society and work-related social problems and access to health services were the major difficulties acknowledged. The patients as well as their families mentioned that education was required to correct misunderstandings about HIV and to assist them to cope with related problems. The findings revealed that patients and their family members were sensitive about disclosure (Kose et al., 2012).

\section{Methods}

The research is qualitative and the data were collected through interviews and analysed with Atlas. ti 8. The target population included: Government, NGOs, Community Leader, Religious Leader and PLWHA. The research adopted a convenient sample of twelve (12) participants as follows: (4 Patients and two Health Workers from Murtala Muhammad Specialist Hospital, Kano State Programme Manager, Family Health International (FHI), the Chairman Godiya Care Foundation, a Member of Godiya Support Group, a Traditional Leader, a Religious Leader and the Director, Prevention, Care and Treatment, KSACA. The sampling technique is purposive and the research design is a case study. 


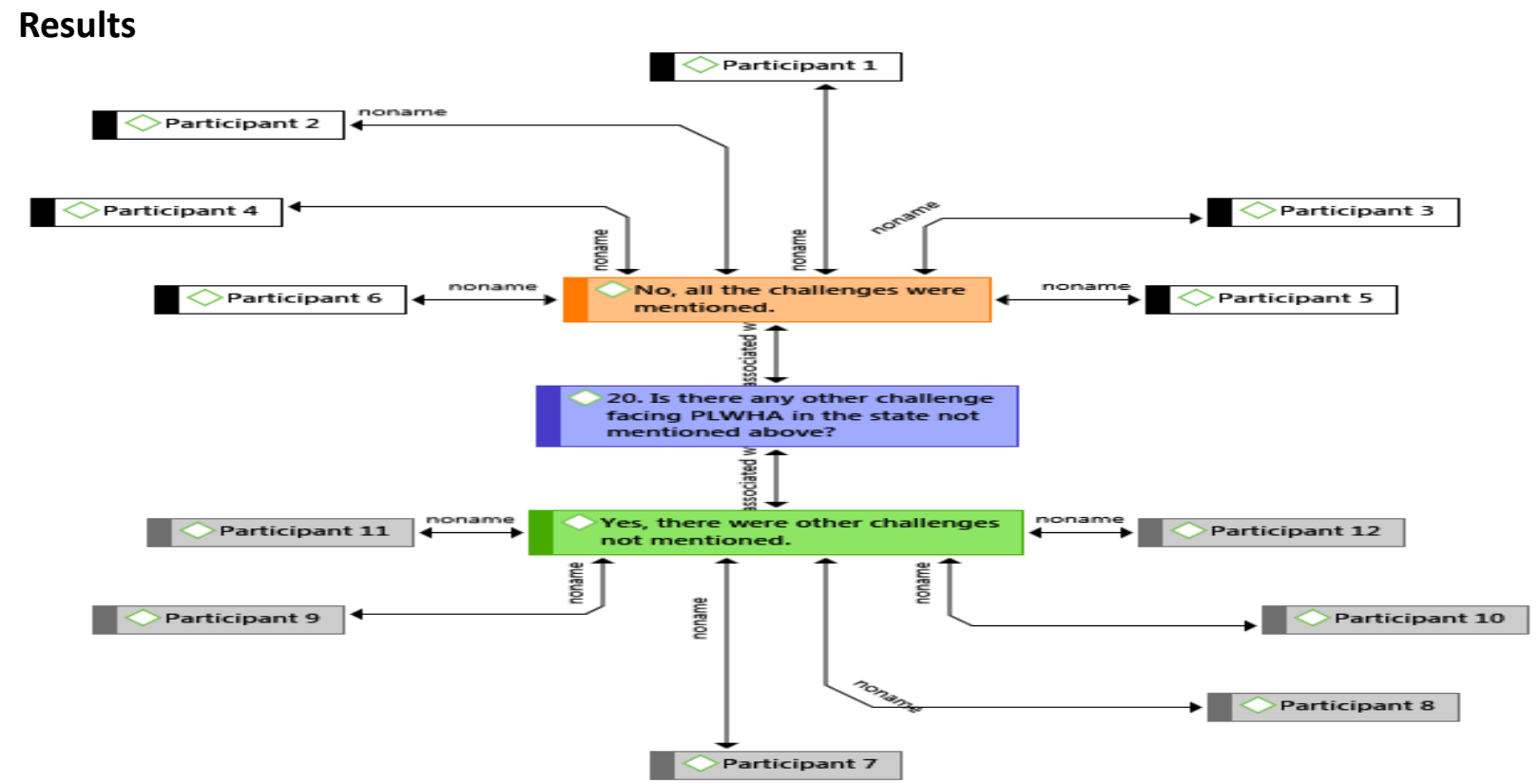

Figure 4.21 Thematic Map of Challenges Facing PLWHA

One of the research objectives is to evaluate the challenges faced by people living with HIV/AIDS in getting social support in Kano state. It is a common issue that people living with HIV/AIDS experience various challenges in the community when they are diagnosed with HIV positive and they disclose their status. Given this, the participants were asked to give their opinion with regards to some challenges they were facing in the community in terms of law and policy made by the government to protect their right, government employment opportunity, provision of free or subsidized and available antiretroviral treatment and full access to government healthcare services. They were finally allowed to state if other challenges were facing them that the researcher did not ask. Six out of the twelve participants stated that there were no other challenges that were not mentioned during the interview. They said that all the major challenges people living with HIV/AIDS in Kano were discussed. The remaining participants presented a contrary opinion by declaring the three were other challenges

On the other hand, the remaining participants identified other challenges that people living with HIV/AIDS in the state were facing which include lack of participation of religious scholars in the state HIV/AIDS affairs, the nonexistence of viral load test gadgets, pulling out of international non-governmental organisations, transportation problem facing the support groups, lukewarm attitude to people living with HIV/AIDS in the state when choosing a marriage partner and after the marriage among themselves or between them and negative people, the issue of disclosure of HIV status due to fear of stigma and discrimination and the boredom of frequent visits to the health facilities to collect ART as the drugs are lifelong. These problems might be very peculiar to people living with HIV/AIDS in Kano state and uncommon in the other parts of the world. Therefore, recommendations were made to stakeholders to find a lasting solution to these identified challenges,

Six participants informed the researcher that all the key challenges facing people living with HIV/IDS in the state were asked by the researcher and responded by the participants as quoted below: 
The government should double its effort in supporting people living with HIV/AIDS (Participant 1). There was no (Participant 2). Sincerely, there was no (Participant 3). Honestly, there was no. All the questions you were supposed to ask were asked (Participant 4). All the challenges facing people living with HIV/AIDS in the state were mentioned (Participant 5). There was no. There was no anything (Participant 6).

One of the challenges facing people living with HIV/AIDS in Kano was a lack of involvement of religious leaders in the state in their affairs. Religious leaders played a very $t$ role in the community and commanded utmost respect. Therefore, they were supposed to be deeply engaged in all the affairs of PLWHA. They were supposed always to preach to people to support them to the best of their ability and avoid anything like stigma and discrimination against them as reported below:

Whatever you were supposed to ask me was asked about family, community, and friends. The positive persons needed counselling and religious leaders needed to intervene in their affairs. I did not know if there was any group or committee of religious leaders that preached about HIV in the state. In most cases, the positive person didn't participate in the counselling programme because they did not like others to know their status due to fear of social exclusion (Participant 7).

Another key challenge facing people living with HIV/AIDS in the state was a lack of viral load test gadgets. The blood samples were taken to Lagos state for viral load test and because of the long duration of the journey sometimes the blood became clotted. So the PLWHA were agitating for the government to provide the test kits to resolve the problem. The assertion of participant 8 confirmed the above statement as quoted below:

In almost all hospitals including Aminu Kano Teaching Hospital, there were no machines for viral load tests, if they were available, it would be better. The blood of a patient was being taken to Lagos state (a whole night journey from Kano) for the test, which was a severe challenge. Patients would be told to come after two weeks for the result and when they came back, sometimes they would be told that the blood clotted during the long journey. So, in the end, there were no results. They had this challenge and they pleaded that the viral load tests should be done in Kano (Participant 8).

People living with HIV/AIDS in the state were facing a serious challenge about the withdrawal of a donor. Some of the international non-government organisations supporting PLWHA in the state had a specific period to render their support and after that, they left. This affected the patients seriously in terms of getting the required services constantly before they got another NGO to continue with similar support as highlighted in the quotation below:

Yes, with the changes in the donors supporting the centre, the quality of care that PLWHA received was affected. Recently, the donor was substituted with another donor and the transition had severely affected the quality of care the patients were 
enjoying. The issue of logistics was highly compromised and the supply of drugs and treatment had been affected. So this had affected them psychologically and even financially. This led to inconsistency in the healthcare delivery and the patients became exhausted and sometimes they missed their medication as they couldn't afford to come without the certainty of getting the services (Participant 9).

The association of people living with HIV/AIDS in the state was facing the problem of a means of mobility. They didn't have transport that would ease their movement within the state and across the states. But Kano State Agency for the Control of Aids was collaborating with the state government to donate a vehicle to the association. This was affirmed by the Director, Care, Prevention and Treatment, KSACA during the interview with the researcher as quoted below:

\begin{abstract}
Well, their significant challenge now was not at an individual level but at the association level. They had been crying for a secretariat and office complex, but the problem was resolved as the Kano State Agency for the Control of Aids gave them an office. But they were agitating for a vehicle to aid their mobility. So the KSACA was collaborating with the government to provide the required transport for them (Participant 10).
\end{abstract}

Moreover, there was a lack of special attention to people living with HIV/AIDS in the state before and after marriage among PLWHA or between them and negative people. The stakeholders ought to play a vital role in such an affair to avoid reinfection and infection among couples. Before marriage, it must be sure that a man and a woman were compatible to get married and after marriage, there must be persistent monitoring of their viral loads. They ought to have adequate counselling programmes in terms of mother-child transmission, antenatal care and safe delivery. This was in line with the quotation below:

The major challenge not mentioned was the issue of marriage between positive and negative persons or between positive and positive persons. Special medical attention and care needed to be rendered to them in terms of frequent checks of their viral load, safe sex and prevention of mother to child transmission and continuous counselling. The infected mothers needed very good antenatal care and experts should carry the delivery (Participant 11).

Another important challenge facing people living with HIV/AIDS in the state was the issue of closure of HIV status because of the fear of stigma and discrimination. Furthermore, the boredom of frequent visits to the health facilities to collect ART because the drugs are lifelong as asserted by Kano state programme manager, $\mathrm{FHI}$ below:

The issue of stigma, social inclusion, rejection and other things were the major challenges. I would share my experience with 
you. I was discussing with somebody who was on treatment and told him that she was finding it difficult. She enrolled in a school and she took her drugs at 9:00 am daily, which coincided with the breakfast period at her school. So she had the fear that people would understand her case and, therefore, stopped taking her drugs at the stipulated time and her viral load increased. Another challenge facing the positive people was the issue of frequent visits to the health facilities to collect their drugs, which were considered tiresome. But to minimize such a problem, patients with stable conditions were given a six-month treatment so that they could only go to the health facilities twice a year. Or, the patients were grouped into five or ten based on their locations and one member would be coming to take the drugs of the group members at specific intervals (Participant 12).

\section{Discussion}

The findings of the research indicated that there were other challenges faced by people living with HIV/AIDS in the state that the participants were not asked in the course of the interview which included a lack of active involvement of religious leaders in the state concerning HIV/AIDS affairs of the positive persons. The religious scholars were very influential in proving support to people living with HIV/AIDS and equally in making the community support the positive persons but were not adequately utilized in providing such support. This might be associated with a belief that they only knowledgeable in Islamic matters and therefore should only handle religious affairs. These findings are similar to the results of Dejman et al (2015) that some participants commended the positive role played by peer groups in counseling patients and in encouraging them for a positive life. Another major challenge was there was no functional viral load test machine in the state. Therefore, the blood samples taken from people living with HIV/AIDS in Kano State had to be taken to Lagos State (a whole night journey) for laboratory investigation and sometimes the blood might have clotted leading to delay in diagnosis and treatment. This demotivates positive patients going to healthcare facilities for treatment. The findings tally with the results of Kose, Mandiracioglu, Mermut, Kaptan, and Ozbel ( 2012) which discovered that the society and work-related social problems and access to health services were the major difficulties acknowledged that PLWHA faced.

Furthermore, the findings showed the international non-government organisations supporting people living with HIV/AIDS usually left the country and therefore the services they provided discontinued if not replaced by other similar NGOs. These findings are in line with the findings of Joseph et al, (2017) that government support in healthcare delivery is inadequate. Hence, the HIV/AIDS programme is heavily supported by international donors. Therefore, an interruption in donors' funding can lead to a negative impact on the health of PLWHA. Again, the results of the research indicated that none of the associations of people living with HIV/AIDS in the state had no vehicle to facilitate their activities in getting support and considering their socioeconomic condition could not afford it. These findings are corroborated by the findings of Moomba and Wyk (2019) in their research carried out in Zambia with HIV patients which indicated that the majority of the patients were jobless and poor. Moreover, findings depicted that people living with HIV/AIDS did not get proper attention and due care when they wanted to get married in terms of compatibility between partners. They were left to marry blindly which might worsen their condition. The findings are 
corroborated by the results of AVERT (2019) that HIV-related discrimination in healthcare remains an issue and is predominantly widespread in some nations. It may be expressed in terms of mandatory HIV testing deprived of consent or suitable counselling. Health personnel can decrease interaction with, or care of, HIV patients, delay or reject treatment, request additional payment for services and separate people living with HIV from other patients.

Still, the findings showed that some positive persons hid their health status because of the fear of stigma and discrimination which could lead to reinfection and the spread of HIV to other people. The results are also in line with findings of Ntseane et al. (2010) that found challenges such as stigma and discrimination, denial and fear of disclosure, as well as risky sexual behaviors were discovered to be widespread. Furthermore, the findings are supported by the findings of Shrestha et al. (2014) which state that concealing the HIV positive status as a key surviving strategy was popular in the family environment. The results also revealed some patients had to travel far to collect their treatment because the ART centres were not located in every locality which made it boring, tiresome and uneconomic. These findings are supported by the findings of Moomba and Wyk, (2019) which disclose that some patients were far from the health facilities and have difficulties in making follow-up clinic appointments, particularly during the rainfall period.

\section{Conclusion}

There were laws and policies in the state enacted by the government to safeguard the human rights of people living with HIV/AIDS. They enjoyed every right and privilege of citizens devoid of restriction. The government employed people living with HIV/AIDS in all the government sectors like other people without the condition. People living with HIV/AIDS in Kano state received free and available and in a rare case, the drugs became out of stock. All the participants had full access to all healthcare facilities in the state. Therefore, they could go to any hospital of their choice for treatment. Some of the challenges facing people living with HIV/AIDS in the state included lack of participation of religious scholars in HIV/AIDS matters, lack of viral load test devices, pulling out of international donors, lack of vehicles for PLWHA, lack of involvement of stakeholders before and after a marriage of PLWHA., the issue of disclosure of HIV status due to fear of stigma and discrimination and frequent visits to ART units to collect their drugs.

\section{Recommendations}

1. Generally, there is a need for consistent and convincing public awareness creation about the means of HIV transmission. Promiscuity should not be considered as the only means of contracting HIV since there are so many other means of transmission.

2. There were laws and policies in the state endorsed by the government to protect the human rights of people living with HIV/AIDS. They had the right of movement, expression, employment, to access social amenities, participate in social gatherings, etc. Some people intentionally or ignorantly contravened such laws and policies and hence intimidated and discriminated against people living with HIV/AIDS. Therefore, the government should reinforce them and punish the defaulters.

3. The religious leaders should be actively involved in providing emotional support to people living with HIV/AIDS in the state. The government and other stakeholders should make a concerted effort in proving adequate viral load machines in the state. It is also recommended that before an international donor leaves, there should be an adequate provision of a substitute. Again. Health experts should be deeply involved 
when HIV positive persons intend to marry for professional advice. Finally, it is suggested that an adequate arrangement should be made in all the health facilities in the state to minimize the frequent visits to health facilities for the sake of drug collection. Drugs that can last for many months should be given or drugs should be dispensed in their localities.

4. The stakeholders should provide vehicles to the associations of people living with HIV/AIDS in the state to ease their mobility.

5. A community-based health centre model was developed and is recommended for the government to implement to improve the quality of life of people living with HIV/AIDS in the state.

\section{References}

AVERT. (2019). HIV Stigma and Discrimination (pp. 1-17). pp. 1-17. Retrieved from https://www.avert.org/professionals/hiv-social-issues/stigma-discrimination

Barre-Sinoussi, F., Chermann, J. C., Rey, F., Nugeyre, M. T., Chamaret, S., Gruest, J., Dauguet, C., Axler-Blin, C., Vezinet-Brun, F., Rouzioux, C., et al. (1983). Isolation of a Tlymphotropic retrovirus from a patient at risk for acquired immune deficiency syndrome (AIDS). Science 220: 868-871 [PubMed] [Google Scholar]

CDC (1981). Kaposi's sarcoma and Pneumocystis pneumonia among homosexual men -New York City and California. MMWR Morb Mortal Wkly Rep 30: 305-308 [PubMed] [Google Scholar]

Dejman, M. (2015). Psychological, Social, and Familial Problems of People Living with HIV_AIDS in Iran_A Qualitative Study

Gallo, R. C., Salahuddin, S. Z., Popovic, M., Shearer, G. M., Kaplan, M., Haynes, B. F., Palker, T. J., Redfield, R., Oleske, J., Safai, B. (1984). Frequent detection and isolation of cytopathic retroviruses (HTLV-III) from patients with AIDS and at risk for AIDS. Science 224: 500-503 [PubMed] [Google Scholar]

Greene, W. C. (2007). A history of AIDS: Looking back to see ahead. Eur J Immunol 37 Suppl. 1: S94-S102 [PubMed] [Google Scholar]

Joseph, B., Abimiku, C., Dangiwa, D., Umar, D., Bulus, K., \& Dapar, M. (2017). Foreign Aid Initiatives and the HIV/AIDS Epidemic in Nigeria: Perspectives on Country Ownership and Humanistic Care. International STD Research \& Reviews, 5(3), 1-14. https://doi.org/10.9734/isrr/2017/34538

Kose, S., Mandiracioglu, A., Mermut, G., Kaptan, F., \& Ozbel, Y. (2012). The Social and Health Problems of People Living with HIV/AIDS in Izmir, Turkey. The Eurasian Journal of Medicine, Vol. 44, pp. 32-39. https://doi.org/10.5152/eajm.2012.07

Moomba, K., \& Wyk, B. V. (2019). Social and economic barriers to adherence among patients at Livingstone General Hospital in Zambia. 1-6.

Nasidi, A., \& Harry, T. O. (2006).The epidemiology of HIV/AIDS in Nigeria. In: Adeyi O., Kanki P.J., Odutolu O., Idoko J.A., editors. AIDS in Nigeria: A Nation on the Threshold. Harvard Center for Population and Development Studies; Cambridge (Massachusetts): Available: < http://www.apin.harvard.edu/Chapter2.pdf> [Google Scholar]

Ntseane, D., Nthomang, K., Segwabe, M., Jankey, O., Simbayi, L., \& Strebel, A. (2010). Challenges facing people living with HIV and AIDS (PLWHA) in Botswana: Implications for behavioural risk reduction intervention. Journal of Social Development in Africa, Vol. 25, pp. 71-96. https://doi.org/10.4314/jsda.v25i2.65057 
Sakirullah, A., \& Mohd, H. (2019). Civil Marriage In The Light Of Fiqh Al-Maqaasid, Nigeria As A Case Study. International Journal Of Academic Research In Business And Social Sciences, 9(4).

Embong, A. H., \& Yasin, M. F. M. (2019). Introduction To Technologised Quranic Learning In Ulul Albab Quranic Studio. Technology, 10(3), 3323-3335.

Odimegwu, C. O., Akinyemi, J. O., \& Alabi, O. O. (2017). HIV-Stigma in Nigeria: Review of Research Studies, Policies, and Programmes. AIDS Research and Treatment, Vol. 2017, pp. 1-13. https://doi.org/10.1155/2017/5812650

Shrestha S., Poudel, K. C., Poudel-Tandukar, K., Kobayashi, J., Pandey, B. D., \& Yasuoka, J. (2014). Perceived Family Support and Depression among People Living with HIV/AIDS in the Kathmandu Valley, Nepal. J Int Assoc Provid AIDS Care. 13(3):214-22. 